7. Пашин В.М. Институт злоупотребления субъективными правами delegeferenda // Актуальные проблемы гражданского права: Сб. статей / Под ред. О.Ю. Шилохвоста. М., 2003. Вып. 7. С. 67-75.

Овчинникова Ю.С.

Кандидат юридических наук, научный сотрудник Института государства и права РАН

\title{
ЗАЩИТА ПРАВ И ЗАКОННЫХ ИНТЕРЕСОВ ПОТРЕБИТЕЛЯ СТРАХОВЫХ УСЛУГ: НЕКОТОРЫЕ АСПЕКТЫ
}

Аннотация

В статье рассмотрены актуальные проблемы защиты прав и законных интересов потребителей страховых услуг. Уделено внимание вопросам правовой замить потребителей страховых услуг в процессе иифровизации, а также при функционировании информачионных систем в страховании, в частности, финансовых платформ. Затронуты некоторые вопросы, возникающие в правоотночениях по страхованию гражданской ответственности владельщев транспортных средств.

Ключевые слова: страхование, потребитель, правовая защита, информация, страхователь, цифровизация

Keywords: insurance, consumer, legal protection, information, insured, digitalization.

Защита прав и законных интересов потребителя страховых услуг как комплекс правовых мер представляет собой весьма актуальную сферу для исследования. Это связано, во-первых, с недостаточной научной разработанностью данной проблематики и, во-вторых, отсутствием в законодательстве необходимых гарантий для потребителя страховых услуг. Кроме того, ученые справедливо отмечают, что в последнее время можно наблюдать особенно широкую вовлеченность обычных граждан в финансовую сферу [1] - в том числе, и страховых услуг.

Наиболее остро данные вопросы встают в процессе цифровизации страховых услуг, что обусловлено, прежде всего, спецификой данного явления. Дело в том, что цифровизация предполагает создание новых способов информирования, являясь серьезным глобальным изменением функционирования всех социальных систем [2]. В данной ситуации особенно уязвимыми оказываются основные права и свободы человека, которые гарантированы в Конституции, то же можно сказать и о положении слабой стороны в обязательстве, в том числе, страховом.

Необходимо признать, что, благодаря развитию цифровых технологий, в настоящее время возможен не только обмен информацией между страховщиком и страхователем в электронной форме, но и заключение договора страхования. Данный фактор, несомненно, способствует активизации потенциальных страхователей и расширению страхового рынка, но, вместе с тем, ввиду несовершенства законодательства, влечет ряд проблем. Главная из них - несоответствие информационных систем в страховании гарантиям Закона РФ «О защите прав потребителей» [3]. Так, согласно данному Закону, потребитель имеет право на предоставление информации в исчерпывающем виде - в том числе, о самой сделке и субъектах, которые ее осуществляют (в данном случае речь идет о страховщике). При этом информация, как известно, имеет огромное значение при формировании воли любого субъекта права, включая потребителя, и по своей природе представляет собой характеристику окружающей действительности, возникающую на 
основе познания и позволяющую различать признаки фактов, явлений, процессов и их связи[4].

Отсюда можно сделать вывод, что права потребителя на информацию означают информированность потребителя, которая должна соответствовать следующим критериям: доступность, исчерпывающий характер, достоверность. Однако на настоящий момент можно говорить об отсутствии полноценной информированности потребителя и, соответственно, его субъективное право на информацию не реализуется в должной мере. Прежде всего, это связано с тем, что законодательство не содержит необходимых критериев для содержания информационных систем.

Так, как известно, страховые услуги могут предоставляться теперь посредством финансовых платформ. С одной стороны, данная возможность позволила облегчить потребителям процесс получения страховой услуги. С другой стороны, поскольку ни Федеральный закон «Об информации, информационных технологиях о защите информации» [5], ни Федеральный закон «О совершении финансовых сделок с использованием финансовой платформы» [6] не определяют требования к содержанию размещенной информации, то это, несомненно, нарушает вышеназванные права потребителя. Фактически содержание и порядок размещения информации определяются не законом, как это должно быть, а операторами финансовых платформ в соответствующих правилах.

Как известно, недавно внесены изменения в Закон РФ «О защите прав потребителей» (п.2 ст.3), [7] согласно которым предполагается создание единого информационного ресурса в области защиты прав потребителей. $\mathrm{B}$ данный информационный ресурс будут включаться также сведения о качестве и безопасности услуг (в том числе, страховых), которые предоставляются потребителям. Однако важно, чтобы в законодательстве содержались также требования к содержанию сведений информационного ресурса об услугах, предоставляемых потребителям- с позиций таких критериев, как доступность, исчерпывающий характер, достоверность. Только в этом случае можно будет говорить о реальных, предоставленных законом гарантиях полноценной информированности потребителей.

Похожие проблемы существуют и в информационных системах в страховании. Так, на основании ст.3.1 Закона РФ «Об организации страхового дела в РФ» [8] была создана единая информационная автоматизированная система, содержащая сведения о договорах страховании средств наземного транспорта и гражданской ответственности владельцев транспортных средств. Дело в том, что данная информационная система на настоящий момент выполняет функцию не полноценной информированности потребителя, как это должно быть, а скорее облегчения администрирования Банка России. Речь идет о том, что Банк России, как известно, рассматривает жалобы граждан по оказанию страховых услуг при этом единая информационная система способствует осуществлению этой функции. Данный вывод можно сделать на основе анализа Указания Банка России от 10.04.2015 № 3620-У[9], в котором содержатся требования к составу сведений данной информационной системы.

Проблемы существуют и в информационных системах страхования жилых помещений. Так, согласно изменениям, в Федеральный закон 21 декабря 1994 года «О защите населения и территорий от чрезвычайных ситуаций природного и техногенного характера» [10] государство и страховые компании совместно участвуют в возмещении ущерба от стихийных бедствий. Участие осуществляется посредством разработки специальных программ возмещения ущерба собственникам и иным правообладателям жилых помещений, заключившим договор добровольного страхования жилья. Речь идет, в частности, о компенсации страховой премии страхователю, финансовой помощи в виде возмещения ущерба-за счет бюджетных средств.

При этом в целях информационной координации была создана информационная система страхования жилых помещений (п.3.2 ст. 3 Закона РФ «Об организации 
страхового дела в РФ»). При этом, на наш взгляд, пробелом законодательства является тот факт, что страхователь не входит в перечень субъектов информационного взаимодействия [11]. Информационная система страхования жилых помещений, таким образом, обеспечивает не информирование страхователей, а скорее процесс координации действий административных органов, что, несомненно, нарушает права и законные интересы страхователей.

Теперь о проблемах защиты прав и законных интересов потребителей в правоотношениях по страхованию гражданской ответственности владельцев транспортных средств [12] (далее-ОСАГО).

Так, как известно, в течение действия договора ОСАГО может произойти ряд изменений, существенно влияющих на увеличение страхового риска. В данной ситуации у страховщика возникает право требовать у страхователя выплаты дополнительной страховой премии. При неисполнении данной обязанности страхователем страховщик вправе заявить в одностороннем порядке о расторжении договора и возмещении убытков (п.5 ст.453 ГК РФ).

Сложность состоит в том, что в страховом законодательстве, в том числе в Правилах страхования [13], не определены обстоятельства, влияющие на увеличение страхового риска. Кроме того, распространены ситуации, когда соответствующие условия договора страхования сформулированы недостаточно четко и существует, соответственно, возможность интерпретации их в пользу страховщика.

Данная проблема свойственна имущественному страхованию в целом, но в страховании гражданской ответственности владельцев транспортных средств она стоит наиболее остро - это связано с тем, что страхователь по закону обязан вступать в страховые правоотношения. Можно сделать вывод, что в страховое законодательство необходимо внести необходимые изменения - речь идет об установлении критериев увеличения степени страхового риска в имущественном страховании.

Еще одна проблема в страховании гражданской ответственности транспортных средств заключается в том, что у некоторых категорий потребителей-потерпевших отсутствует право выбора страховой услуги. В целом страховое возмещение в ОСАГО может осуществляться как посредством выдачи потерпевшему страховой выплаты, так и путем организации и оплаты страховщиком восстановительного ремонта поврежденного транспортного средства (возмещение причиненного вреда в натуре). Однако для определенной категории потерпевших, а именно, гражданам, которые являются собственниками легковых автомобилей, зарегистрированных в РФ, не предоставлено право выбора страховой услуги (ст.15.1 Закона об ОСАГО). Соответственно, страховое возмещение вреда в пользу таких потерпевших осуществляется только посредством оплаты восстановительного ремонта поврежденного транспортного средства (возмещение причиненного вреда в натуре). При этом только в некоторых случаях граждане, которым принадлежат на праве собственности автомобили, зарегистрированные в РФ, могут выбрать форму страхового возмещения, а именно - при причинении здоровью потерпевших тяжкого или средней тяжести вреда, а также инвалидности последних.

По нашему мнению, право выбора страховой услуги должно в равной мере принадлежать потерпевшим всех категорий. Данный вывод можно сделать по следующим причинам. Во - первых, отсутствие права выбора страховой услуги противоречит принципу справедливости в гражданском праве (п.2 ст.6 ГК РФ) и, во-вторых, правовой природе договора ОСАГО, который имеет публичный характер. Как известно, недопустимо, чтобы условия публичного договора устанавливали преимущества или предпочтения отдельным категориям потребителей, кроме ситуаций, когда им предоставляется льгота (п.2 ст.426 ГК РФ).

При этом правовая сущность льготы состоит в дополнительных правах или определенных преимуществах, установленных законом в сфере социального обеспечения. Данные преимущества не имеют прямого отношения к возможности выбора услуги 
субъектами гражданского права, которые должны находиться в равном положении. Таким образом, преимущество, в котором оказались определенные субъекты ОСАГО (гражданесобственники транспортных средств, которые зарегистрированы на территории РФ, и юридические лица) не относится по своей правовой природе к льготе и противоречит п. 2 ст.426 ГК РФ.

Не менее актуальной является проблема определения размера страхового возмещения после страховых случаев по ОСАГО. При оценке страховых убытков используются экономические критерии - стоимость восстановительного ремонта, утрата товарной стоимости, реальный ущерб, амортизация имущества. Можно сказать, что объективность оценки страховых убытков имеет правовое значение, поскольку от данного фактора зависит защита интересов потерпевших - это относится как к восстановительному ремонту транспортного средства, так и к страховой выплате. Однако, на наш взгляд, в этом вопросе права и законные интересы потерпевших оказываются ущемленными. Это связано с тем, что по Закону об ОСАГО (п.12 ст.12) при согласовании размера страхового возмещения проведение независимой технической экспертизы для определения размера страховых убытков необязательно. Однако независимая техническая экспертиза по поводу оценки размера страховых убытков должна проводиться и являться обязанностью сторон. Дело в том, что при отсутствии результатов независимой экспертизы возможна необъективность при оценке размера страховых убытков. Соответственно, в этом случае не реализуются принципы разумности и справедливости и полного возмещения вреда в гражданском праве.

Теперь о позитивных моментах правового регулирования страховых правоотношений с точки зрения защиты законных интересов - как потребителей, так и слабой стороны договоров в целом. В частности, речь идет о принципе недопустимости одностороннего отказа от исполнения обязательства.

Довольно существенные изменения в содержание данного принципа внесла реформа гражданского права, а именно, дополнительные гарантии предоставлены стороне, которая не осуществляет предпринимательскую деятельность. Конкретнее - в договоре может быть предусмотрено право слабой стороны (не осуществляющей предпринимательскую деятельность) на односторонний отказ от исполнения обязательства и одностороннее изменение его условий (п.2 ст.310 ГК РФ). До реформы гражданского права односторонний отказ от исполнения обязательства и одностороннее изменение его условий допускался только по основаниям, которые предусмотрены в законе.

Цель вышеназванного изменения в ГК РФ - защита интересов слабой стороны обязательства. В страховых правоотношениях слабой стороной являются как граждане, так и все виды юридических лиц и индивидуальные предприниматели. Это объясняется тем, что все перечисленные субъекты (в том числе, осуществляющие предпринимательскую деятельность) вступают в страховые правоотношения с целью получения страховой защиты.

Данное правило о возможности одностороннего отказа от исполнения обязательства для стороны, которая не осуществляет предпринимательскую деятельность, охватывает все виды договоров страхования - как публичного, так и непубличного характера. При этом данные изменения не играют столь серьезной роли для публичных договоров [14] (например, речь идет о договоре личного страхования, договоре страхования гражданской ответственности владельцев транспортных средств), поскольку публичные договоры не предполагают возможность отказа предпринимателя от договора. Следовательно, принцип недопустимости одностороннего отказа от исполнения обязательства действует в таких договорах в силу их публичности.

Договор страхования - это соглашение между страхователем и страховщиком, в соответствии с условиями которого страховщик обязуется компенсировать ущерб в той или иной форме либо выплатить страхователю или выгодоприобретателю определенную денежную сумму при наступлении предусмотренного договором страхового случая. 
Страхователь по договору страхования обязуется выплатить страховщику страховую премию, выполнять ряд других обязанностей и соблюдать предусмотренные соглашением ограничения[15].

Наоборот, для договоров, которые не являются публичными, изменения п.2 ст. 310 ГК РФ имеют существенное значение - речь идет о некоторых видах договоров страхования имущества, а также страхования ответственности по договору и предпринимательского риска. Несомненно, после введения вышеназванных изменений появились дополнительные гарантии защиты интересов страхователей - участников данных договоров.

В последнее время в страховое законодательство были внесены изменения - при этом, к сожалению, остались нерешенными серьезные проблемы страховых правоотношений, которые касаются всех страхователей и выгодоприобретателей - в том числе, потребителей страховых услуг.

Проблемы правового регулирования имущественного страхования заключаются, прежде всего, в отсутствии механизмов защиты интересов страхователей и выгодоприобретателей. Таким образом, направление по защите прав страхователей, которое было закреплено в Концепции развития страхования, не реализовано в законах. Это происходит, во-первых, по причине отсутствия правовой базы. Дело в том, что в 1996 году из Закона РФ «Об организации страхового дела в РФ» [16] была исключена глава «договор страхования». Соответственно, с этого момента регулирование договорных страховых отношений осуществляется исключительно главой 48 ГК РФ, которая не содержит многих важных положений, например, об особенностях заключения и прекращения договора страхования, о правах и обязанностях сторон, о порядке осуществления страховой выплаты, об особенностях ответственности страховщика. Кроме того, в данной главе отсутствует различие в регулировании страховых отношений с участием граждан и предпринимателей.

Не менее актуальной является проблема определения степени страхового риска. Согласно действующему законодательству «критерием» определения степени страхового риска выступает позиция страховщика.

На практике это нередко приводит к злоупотреблениям со стороны страховщика. Договоры страхования или письменные запросы нередко содержат нечеткие формулировки, при которых определять степень риска можно в свою пользу. Вместе с тем этот вопрос затрагивает интересы страхователя. Это связано с тем, что от степени риска напрямую зависит размер страховой премии, уплачиваемой страховщику - чем выше степень риска, тем больше страховая премия.

Подобные проблемы возникают при оценке страховой стоимости имущества. Так, для страхования имущества и предпринимательского риска действительная (или иначе страховая) стоимость имущества является основополагающим критерием для оценки страхового интереса [17]. Однако для полноценной защиты интереса необходимо, чтобы страховая стоимость была правильно отражена в договоре. При этом в законодательстве отсутствуют механизмы, обеспечивающие точное закрепление действительной стоимости в договоре.

Таковы основные проблемы защиты прав и законных интересов потребителей страховых услуг. Некоторые из них относятся к слабой стороне договора страхования в целом - страхователям, а также выгодоприобретателям. Решение данных проблем возможно только путем реформирования страхового законодательства с учетом принципов гражданского права.

\section{Литература}

1.Фогельсон Ю.Б.; Ефремова М.Д. Защита прав потребителей финансовых услуг. М: Норма, 2010. С. 2. 
2. Грибанов Ю.И. Цифровая трансформация социально-экономических систем на основе развития института сервисной интеграции. Автореферат диссертации на соискание ученой степени доктора экономических наук. Санкт-Петербург, 2019. С.6.

3. Закон РФ от 7 февраля 1992 г. (ред. от 11 июня 2021 г.) № 2300-1 «О защите прав потребителей»; Российская газета от 7 апреля 1992 г.

4. Бачило И.Л. Информационное право. Москва: Юрайт, 2017. С. 25.

5. ФЗ от 27 июля 2006 г. (в ред. от 9 марта 2021 года) 149-Ф3 «Об информации, информационных технологиях о защите информации»; Российская газета от 29 июля 2006 № 165 .

6. Федеральный закон от 20 июля 2020 года № 211-Ф3 «О совершении финансовых сделок с использованием финансовой платформы»; Российская газета от 24 июля 2020 года, № 162.

7. Федеральный закон от 11 июня 2021 № 170-Ф3 «О внесении изменений в отдельные законодательные акты РФ в связи с принятием ФЗ « О государственном контроле (надзоре) и муниципальном контроле в РФ»; Российская газета от 18 июня 2021 г., № 133. 8. Закон РФ от 27 ноября 1992 года № 4015 -1 (ред. от 30 декабря 2020 г) «Об организации страхового дела в РФ»; Российская газета от 12 января 1993 № 6.

9. Указание Банка России от 10 апреля 2015 года № 3620-У «О порядке создания и эксплуатации единой автоматизированной системы и перечнях видов информации, предоставляемой страховщиками» - См. СПС Консультант плюс.

10. Федеральный закон от 21 декабря 1994 года (ред. от 26.05.2021) № 68-Ф3 «О защите населения и территорий от чрезвычайных ситуаций природного и техногенного характера»; СЗ РФ ,1994, № 35, ст.3648.

11. Постановление Правительства РФ от 30.07.2019 № 984 (ред. от 17.02.2021) «Об утверждении Правил информационного взаимодействия единой автоматизированной системы страхования жилых помещений с информационными ресурсами федеральных органов исполнительной власти, органов государственной власти субъектов РФ и Центрального банка РФ».

12. Федеральный закон от 25 апреля 2002 года № 40-Ф3 «Об обязательном страховании гражданской ответственности владельцев транспортных средств»// Российская газета, 2002. № 80 .

13.Положение Банка России от 19 сентября 2014 г.№ 431-П «О правилах обязательного страхования гражданской ответственности владельцев транспортных средств» /СПС «Консультант плюс» (дата обращения 26.11.2019).

14. С.С. Занковский. Предпринимательские договоры. М: Волтерс Клувер, 2004. С. 28. 15. Интернет - ресурс // Материал из Википедии - свободной энциклопедии.

15. Распоряжение Правительства РФ от 25.09.2002 № 1361-р «О концепции развития страхования в РФ».

16. Абрамов. В.Ю. Страховое право-теория и практика/ Москва; Изд-во «Анкил», 2007. C.45. 